\title{
OPEN Laurinterol from Laurencia johnstonii eliminates Naegleria fowleri triggering PCD by inhibition of ATPases
}

\author{
Iñigo Arberas-Jiménez ${ }^{1,2,3,7}$, Sara García-Davis ${ }^{4,7}$, Aitor Rizo-Liendo ${ }^{1,2}$, Ines Sifaoui ${ }^{1,2,3,5}$, \\ María Reyes-Batlle ${ }^{1,2,3,5}$, Olfa Chiboub ${ }^{1,5}$, Rubén L. Rodríguez-Expósito ${ }^{1,2,3}$, \\ Ana R. Díaz-Marrero ${ }^{4}$, José E. Piñero ${ }^{1,2,3 \bowtie}$, José J. Fernández ${ }^{4,6 \bowtie} \&$ \\ Jacob Lorenzo-Morales ${ }^{1,2,3 凶}$
}

Primary amoebic encephalitis (PAM) is a lethal disease caused by the opportunistic pathogen, Naegleria fowleri. This amoebic species is able to live freely in warm aquatic habitats and to infect children and young adults when they perform risk activities in these water bodies such as swimming or splashing. Besides the need to increase awareness of PAM which will allow an early diagnosis, the development of fully effective therapeutic agents is needed. Current treatment options are amphotericin B and miltefosine which are not fully effective and also present toxicity issues. In this study, the in vitro activity of various sesquiterpenes isolated from the red alga Laurencia johnstonii were tested against the trophozoite stage of a strain of Naegleria fowleri. Moreover, the induced effects (apoptotic cell death) of the most active compound, laurinterol (1), was evaluated by measuring DNA condensation, damages at the mitochondrial level, cell membrane disruption and production of reactive oxygen species (ROS). The obtained results demonstrated that laurinterol was able to eliminate the amoebae at concentrations of $13.42 \pm 2.57 \mu \mathrm{M}$ and also to induced programmed cell death (PCD) in the treated amoebae. Moreover, since ATP levels were highly affected and laurinterol has been previously reported as an inhibitor of the $\mathrm{Na}^{+} / \mathrm{K}^{+}$-ATPase sodium-potassium ion pump, comparison with known inhibitors of ATPases were carried out. Our results points out that laurinterol was able to inhibit ENA ATPase pump at concentrations 100 times lower than furosemide.

Naegleria fowleri species, also known as brain eating amoebae is an opportunistic pathogenic amoebae which is able to colonize the central nervous system (CNS) causing an infection known as primary amoebic meningoencephalitis $(\mathrm{PAM})^{1-3}$. The disease affects mainly healthy children and young adults who have reported previous nasal exposure to amoebae-contaminated water during the practice of risk activities such as diving, splashing, among others, in warm water bodies. Moreover, the incidence of PAM since the year 2000 has seen an increase worldwide as it has been recently reported ${ }^{4}$.

Primary amoebic encephalitis was first reported in 1965 in Australia ${ }^{5}$. Since then, PAM cases have been recorded worldwide and it is usually described as a rare disease with only 431 cases available in the literature ${ }^{4}$.

Naegleria fowleri infects humans by passing the nerves and entering the cribiform plate. After that, the amoebae have free entrance to the brain causing inflammation and necrosis ${ }^{2,6-8}$. Hence, the fulminant nature of this infection which normaly manifests in the patient with symptons such as intense headache, temperature,

\footnotetext{
${ }^{1}$ Instituto Universitario de Enfermedades Tropicales y Salud Pública de Canarias (IUETSPC), Universidad de La Laguna (ULL), Avda. Astrofísico F. Sánchez, s/n, 38203 La Laguna, Tenerife, Spain. ${ }^{2}$ Departamento de Obstetricia y Ginecología, Pediatría, Medicina Preventiva y Salud Pública, Toxicología, Medicina LegalY Forense Y Parasitología, Universidad de La Laguna (ULL), Avda. Astrofísico F. Sánchez, s/n, 38206 La Laguna, Tenerife, Spain. ${ }^{3}$ Red de Investigación Colaborativa en Enfermedades Tropicales (RICET), Madrid, Spain. ${ }^{4}$ Instituto Universitario de Bio-Orgánica Antonio González (IUBO AG), Universidad de La Laguna (ULL), Avda. Astrofísico F. Sánchez, 2, 38206 La Laguna, Tenerife, Spain. ${ }^{5}$ Laboratoire Matériaux-Molécules Et Applications, La Marsa, University of Carthage, Tunis, Tunisia. ${ }^{6}$ Departamento de Química Orgánica, Universidad de La Laguna (ULL), Avda. Astrofísico F. Sánchez, s/n, 38206 La Laguna, Tenerife, Spain. ${ }^{7}$ These authors contributed equally: Iñigo Arberas-Jiménez and Sara García-Davis. ${ }^{\circledR}$ email: jpinero@ull.edu.es; jjfercas@ull.edu.es; jmlorenz@ull.edu.es
} 
<smiles>[R]c1cc(C2(C)CCCC2(C)C)c(O)cc1C</smiles>

$1, \mathrm{R}=\mathrm{Br}$<smiles>C=C1[C@H](C)CCC1(C)c1cc(Br)c(C)cc1O</smiles>

3<smiles>C=C1CCC(C)(c2cc(Br)c(C)cc2O)[C@H]1C</smiles>

4

Figure 1. Structure of phenolic sesquiterpenes isolated from Laurencia species.

\begin{tabular}{|l|l|l|}
\hline Sample & $\mathbf{I C}_{\mathbf{5 0}}(\boldsymbol{\mu M})$ & $\mathbf{C C}_{\mathbf{5 0}}(\boldsymbol{\mu M})$ \\
\hline Laurinterol (1) & $13.42 \pm 2.57$ & $80.11 \pm 7.79$ \\
\hline Debromolaurinterol (2) & $18.76 \pm 4.03$ & $70.13 \pm 12.94$ \\
\hline Isolauritenol (3) & $28.18 \pm 0.13$ & $24.74 \pm 2.39$ \\
\hline Amphotericin B & $0.12 \pm 0.03$ & $>200$ \\
\hline
\end{tabular}

Table 1. Effect of phenolic sesquiterpenes 1-3, isolated from Laurencia johnstonii, against Naegleria fowleri ATCC 30,808 $\left(\mathrm{IC}_{50}\right)$ and murine macrophages J774.A1 cell line $\left(\mathrm{CC}_{50}\right)$.

seizures and stiff neck. In the final stage of the disease, patients have been reported to suffer from hallucinations and paralysis previous reaching coma and death ${ }^{6-8}$. Furthermore, the average time of symptoms appearance after infection starts 1-9 days after exposure to contaminated water sources whereas patient death average is 1-18 after symptoms begin ${ }^{4,9}$.

Regarding diagnosis of PAM, it is often undertaken post-mortem because the clinical symptons are not specific. Therefore, late diagnostics correlates to delayed treatment which commonly ends with the lost of the patients $^{1,10,11}$. Current therapeutic options involves a combination of drugs which includes amphotericin B, azithromycin, rifampin, azoles and lately miltefosine with or without the combination of hypothermia ${ }^{6,12,13}$. Even though, recent cases of PAM treatment have been reported to be successful ${ }^{14-16}$, there is still an urgent need to find novel anti-amoebic agents which are able to eliminate the pathogen also causing low toxicity.

Natural products have been used for the treatment of different parasitic diseases, among them artemisinin, quinine and ivermectin are examples of important antiparasitic compounds from this origin ${ }^{17-19}$. Moreover, and specially in the case of antiamoebic compounds, algae have recently revealed their potential as a source of compounds with therapeutic potential ${ }^{20,21}$.

The genus Laurencia is one of the richest sources of active compounds among red algae which have also previously revealed metabolites presenting antiprotozoal and antiparasitic properties ${ }^{22-24}$. However, no activity of these metabolites has been previously reported against Naegleria fowleri.

In the present study, previously identified sesquiterpenes from Laurencia johnstonii species in our group were re-isolated and evaluated against the trophozoite stage of a type strain of Naegleria fowleri. Furthermore, the most active molecule was further investigated in order to establish the mechanisms of programmed cell death induced in the treated amoebae.

\section{Results}

A series of natural phenolic sesquiterpenes (1-3) (Fig. 1) obtained from specimens of Laurencia jonhstonii were selected to screen their in vitro activities against Naegleria fowleri. The obtained results which are shown in Table 1, revealed that laurinterol (1) was the most active molecule with an $\mathrm{IC}_{50}$ of $13.42 \pm 2.57 \mu \mathrm{M}$. Therefore this compound was selected for further studies focused on the study of the induced mechanisms of programmed cell death in the treated amoebae.

Laurinterol eliminates Naegleria fowleri trophozoites at low concentrations and presents low cytotoxicity levels. Laurinterol eliminated $N$. fowleri trophozoites when incubated in vitro in a dose dependent way. The obtained results using the Alamar Blue colorimetric assay (described in the "Methods" section) allowed us to establish an $\mathrm{IC}_{50}$ value of $13.42 \pm 2.57 \mu \mathrm{M}$ (Fig. 2). Furthermore, toxicity assays against the murine macrophage J774.A1 cell line yielded a $\mathrm{CC}_{50}$ of $80.11 \pm 7.79 \mu \mathrm{M}$. Therefore, the toxicity was considered low when compared to the obtained Naegleria inhibitory concentrations of laurinterol.

Moreover, amoebic forms were observed to present morphological changes such as loss of complexity in the cytoplasm and lack of cellular structure as well as cell volume (Fig. 3), at $1 \mathrm{~h}$ time of incubation in the presence of laurinterol at the $\mathrm{IC}_{90}(101.69 \pm 0.67 \mu \mathrm{M})$.

Laurinterol-treated amoebae stained positive in the double stain assay. Laurinterol induced chromatic condensation of treated amoebae at a concentration of $\mathrm{IC}_{90}$. Treated amoebae showed the typical bright-blue stained nuclei at $24 \mathrm{~h}$ post incubation with the molecule as shown in Figs. 4 and 5. 

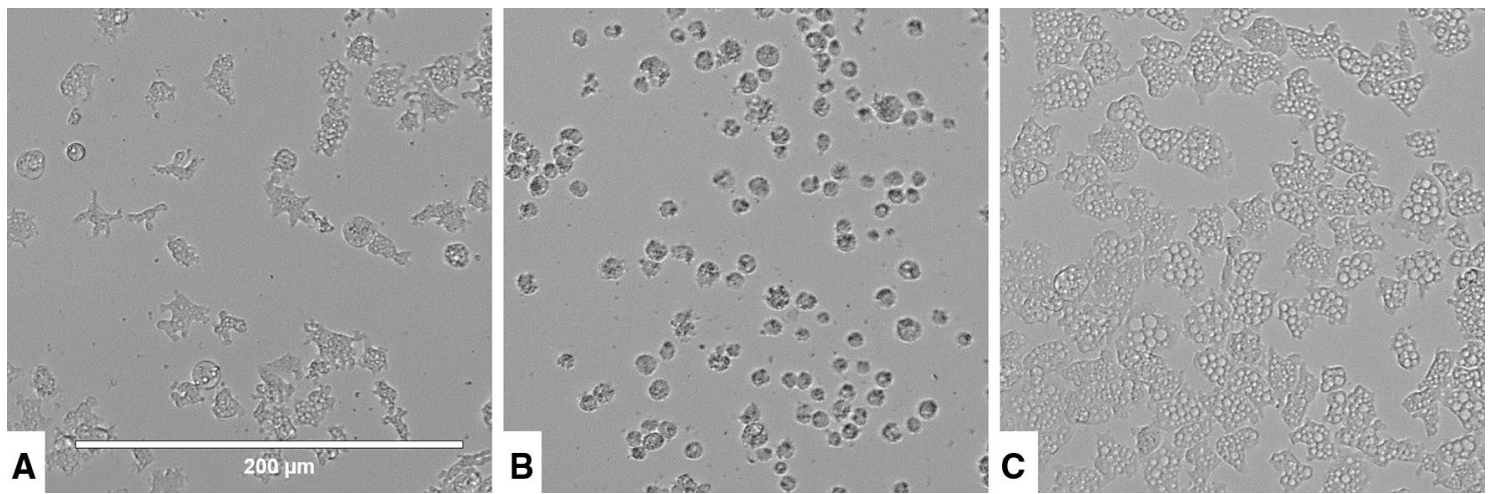

Figure 2. Naegleria fowleri trophozoite incubated with the $\mathrm{IC}_{50}(\mathbf{A})$ and $\mathrm{IC}_{90}(\mathbf{B})$ of laurinterol $(\mathbf{1})(48 \mathrm{~h})$. Images are representative of the cell population observed in the performed experiments. Negative control (C). Images $(20 \times)$ were obtained using an EVOS FL Cell Imaging System AMF4300, Life Technologies, Madrid, Spain.
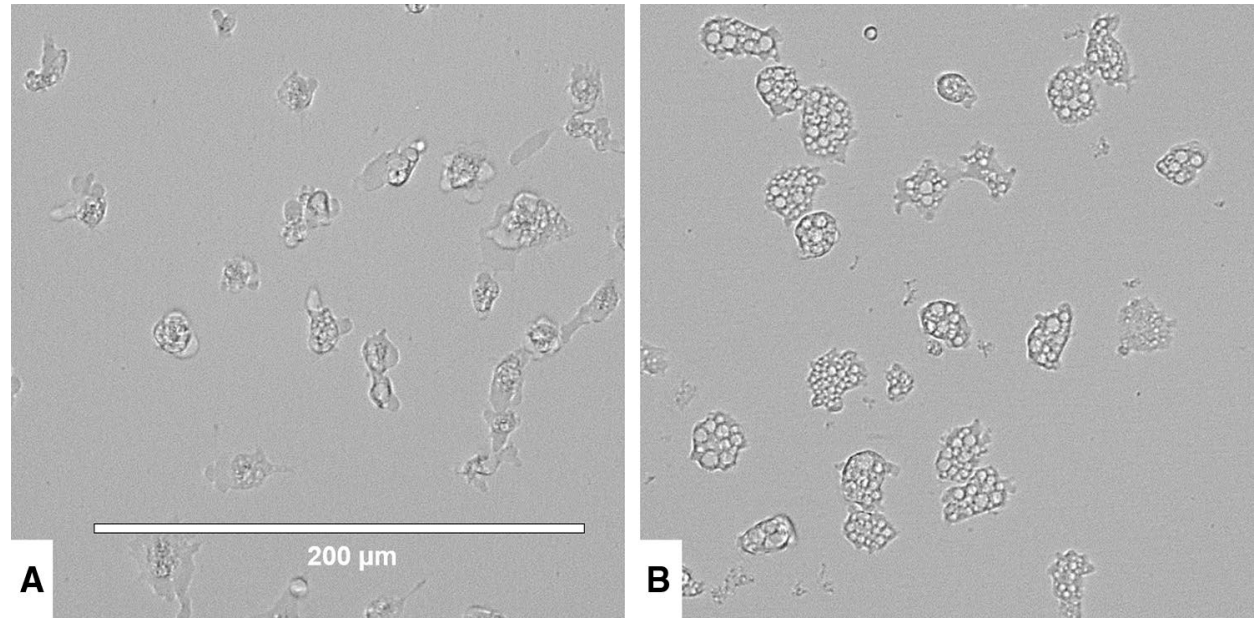

Figure 3. Effect of the $\mathrm{IC}_{90}$ of laurinterol (1) in Naegleria fowleri trophozoite after $1 \mathrm{~h}$ of incubation (A). Images are representative of the cell population observed in the performed experiments. Negative control (B). Images $(20 \times)$ were obtained using an EVOS FL Cell Imaging System AMF4300, Life Technologies, Madrid, Spain.

Laurinterol-treated amoebae showed plasma membrane permeability. As shown in Figs. 6 and 7 , amoebae treated with the $\mathrm{IC}_{90}$ of laurinterol experienced plasmatic membrane damage after $24 \mathrm{~h}$ of incubation.

Laurinterol causes mitochondrial malfunction in treated amoebae. Laurinterol induced changes on the mitochondrial potential of Naegleria fowleri treated trophozoites since the JC-1 dye remained in the cytoplasm in its monomeric form, shown as green fluorescence (Figs. 8, 9). Furthermore, the mitochondrial damage was also checked by measuring the generated ATP levels in $24 \mathrm{~h}$. The observed results showed that laurinterol $\mathrm{IC}_{90}$ treated amoebae presented a $97.36 \%$ decrease of ATP levels when compared to untreated cells. Moreover, since laurinterol has been reported as an inhibitor of the $\mathrm{Na}^{+} / \mathrm{K}^{+}$-ATPase sodium-potassium ion pump ${ }^{25}$, activity assays of known inhibitors including ouabain and furosemide were carried out. Amoebae showed to be ouabaininsensitive even at high concentrations of this product whereas furosemide showed an $\mathrm{IC}_{50}$ of $0.71 \pm 0.04 \mathrm{mM}$.

Laurinterol increases reactive oxygen species (ROS) levels in Naegleria fowleri. Naegleria fowleri trophozites treated with laurinterol experienced increased levels of ROS when treated with $\mathrm{IC}_{90}$ after $24 \mathrm{~h}$ of incubation (Figs. 10 and 11).

\section{Discussion}

The marine environment is an interesting source of bioactive compounds which could be potential novel therapeutic agents against cancer and parasites, among others, as it has been previously described ${ }^{25}$. Furthermore, algae are currently the major source of these type of molecules being Laurencia genus one of the richest organisms among the reported ones so $\mathrm{far}^{21,25}$. In a recent study by García-Davis ${ }^{25}$, the study of species adapted to live 

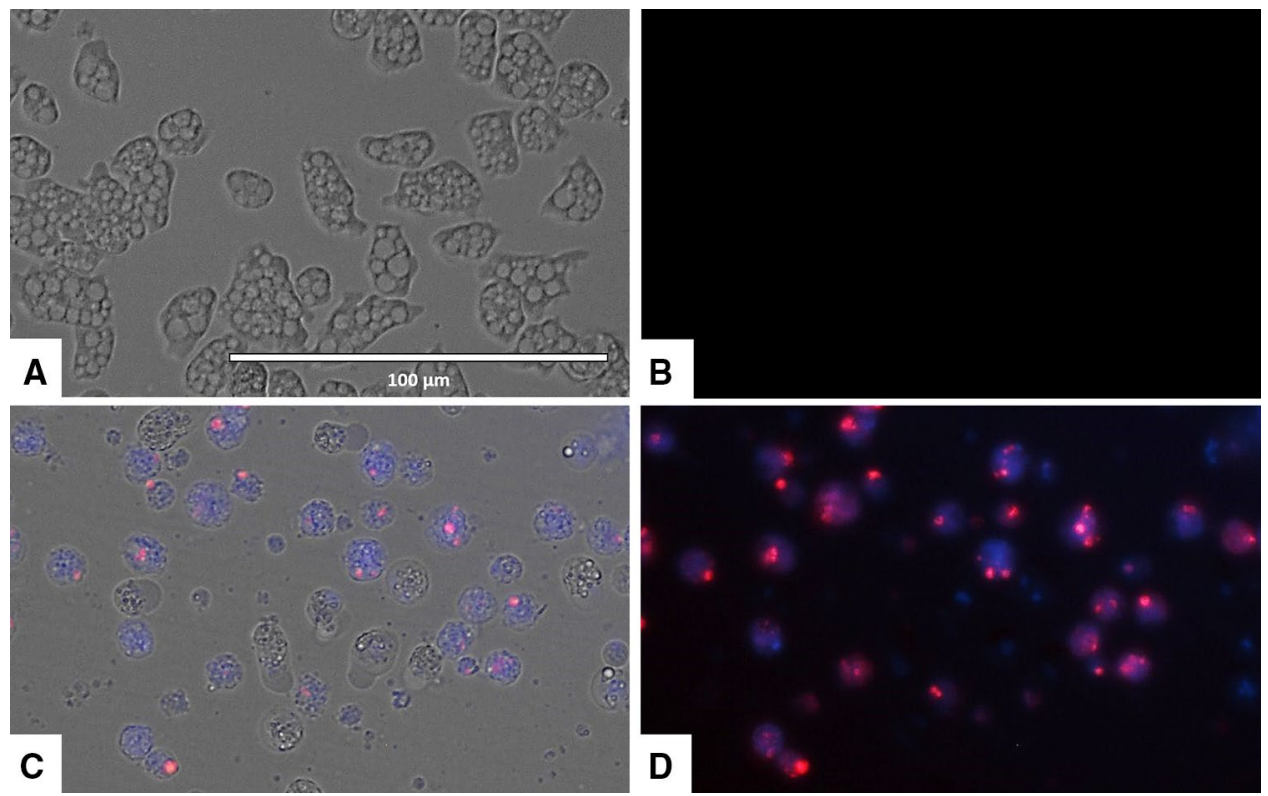

Figure 4. Naegleria fowleri trophozoites incubated with $\mathrm{IC}_{90}$ of laurinterol (1) for $24 \mathrm{~h}$. Hoechst stain is different in control cells, where uniformly faint-blue nuclei are observed $(\mathbf{A}, \mathbf{B})$, and in treated cells, where the nuclei are bright blue $(\mathbf{C , D})$. Red fluorescence corresponds to the propidium iodide stain. Images $(40 \times)$ are showing chromatin condensation (blue) in treated cells. Images are representative of the cell population observed in the performed experiments. Images were obtained using an EVOS FL Cell Imaging System AMF4300, Life Technologies, Madrid, Spain.

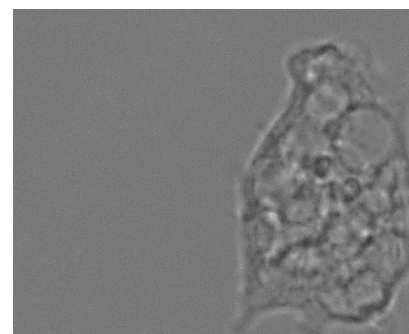

A

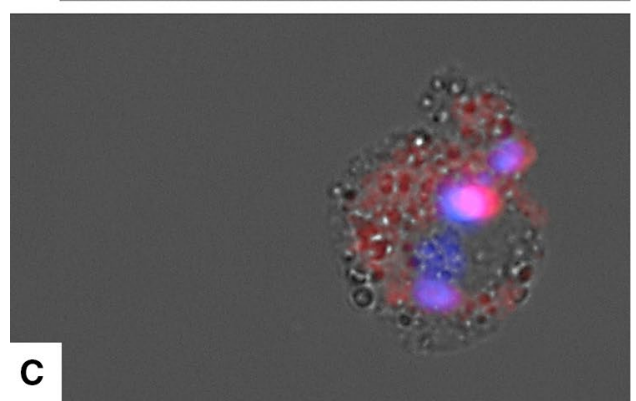

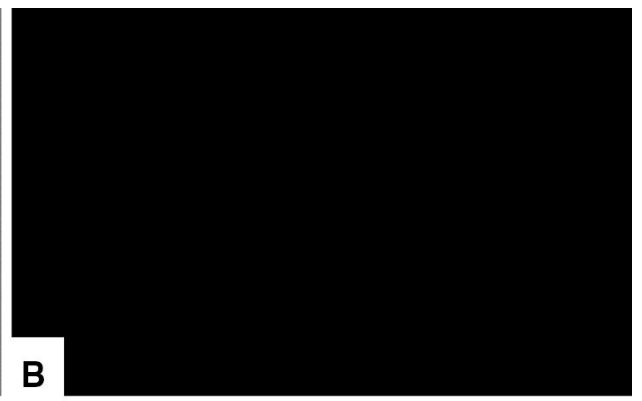

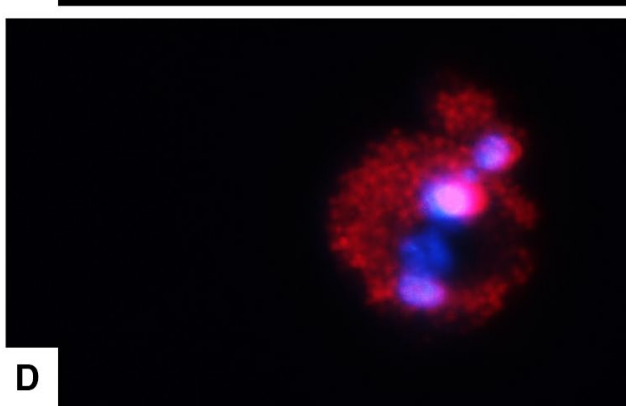

Figure 5. Higher magnification of Fig. 4. Images $(100 \times)$ are showing late apoptotic cell with high blue and red fluorescence. Images are representative of the cell population observed in the performed experiments. Images were obtained using an EVOS FL Cell Imaging System AMF4300, Life Technologies, Madrid, Spain.

under particular environmental conditions, such as L. johnstonii, could be a key factor in the search of potential therapeutic agents from these sources. Interestingly, the species of $L$. johnstonii, endemic from the Pacific coast of the Baja California area, used in this study was reported to present higher contents of laurinterol (1) than its counterparts in the Pacific coast ${ }^{20,25}$.

Primary amoebic encephalitis (PAM) caused by Naegleria fowleri species, a Free-Living Amoebae which is able to act as an opportunistic pathogen, is a fulminant CNS disease which needs novel, more effective and faster 

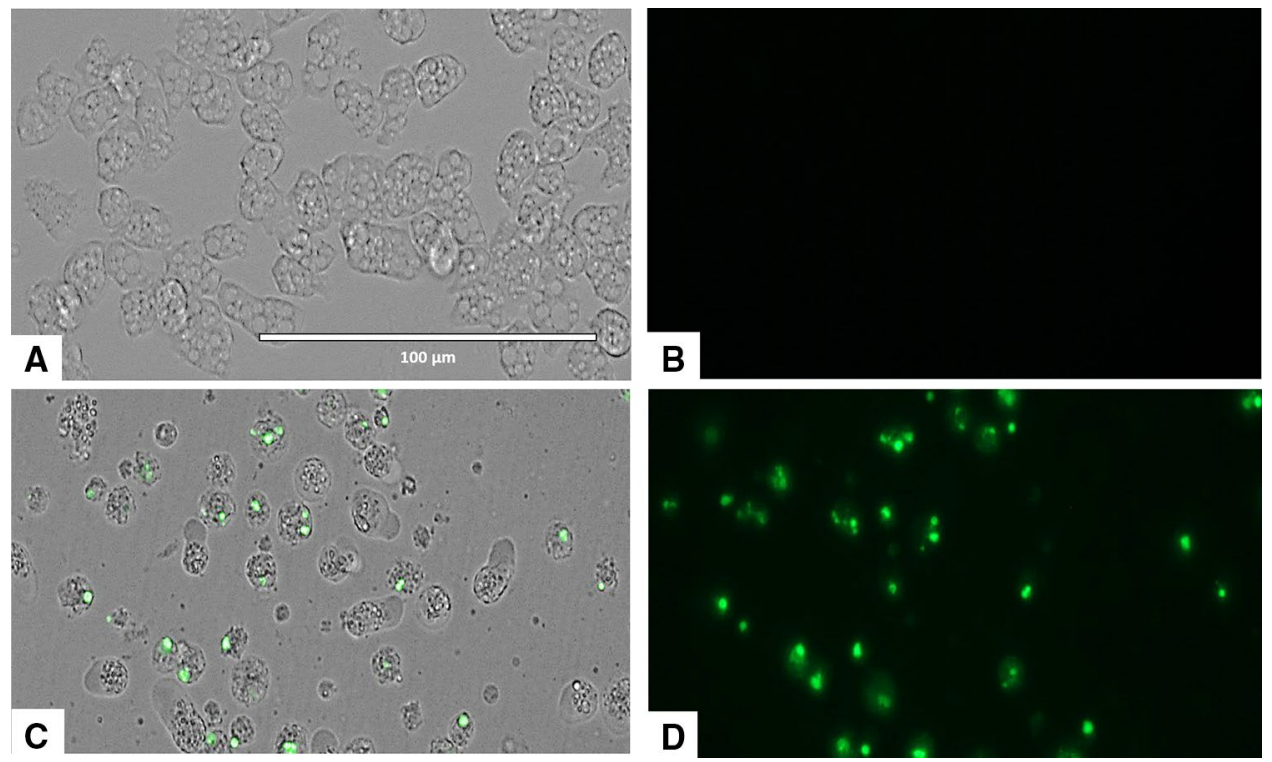

Figure 6. Permeation of the Naegleria fowleri plasma membrane to the vital dye SYTOX green caused by addition of laurinterol (1) at $\mathrm{IC}_{90}$ after $24 \mathrm{~h}(\mathbf{C}, \mathbf{D})$. Negative Control $(\mathbf{A}, \mathbf{B})$. Images $(40 \times)$ are representative of the cell population observed in the performed experiments. Images were obtained using an EVOS FL Cell Imaging System AMF4300, Life Technologies, Madrid, Spain.
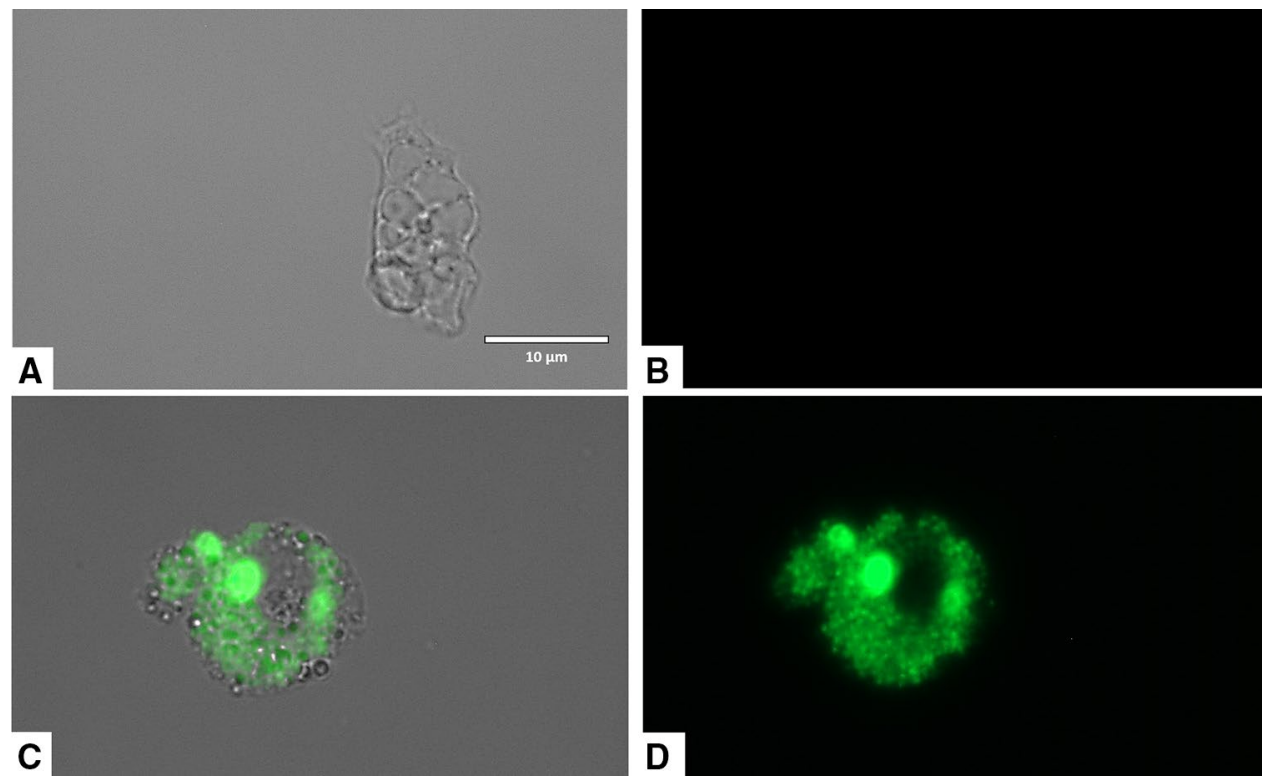

Figure 7. Higher magnification of Fig. $6(100 \times)$. Negative control $(\mathbf{A}, \mathbf{B})$. Cells treated with the $\mathrm{IC}_{90}$ of laurinterol (1) for $24 \mathrm{~h}$. Images were obtained using an EVOS FL Cell Imaging System AMF4300, Life Technologies, Madrid, Spain.

therapeutic options. Furthermore, the current options are not fully effective and lack of availability worldwide creates the need to find alternative options and sources ${ }^{4,13}$.

In this study, we aimed to investigate the potential of some natural sesquiterpenes isolated from L. johnstonii against Naegleria fowleri in vitro. Regarding the obtained activities against the trophozoite stage, it is important to highlight that the most active tested compound, laurinterol was active at low concentrations although not as active as the commonly used therapeutic agent against Naegleria which is amphotericin $\mathrm{B}\left(\mathrm{IC}_{50}=0.12 \pm 0.03\right.$ and $\left.\mathrm{CC}_{50} \geq 200 \mu \mathrm{M}\right)^{9}$. Nevertheless, laurinterol is a small molecule which could be even synthetized in the laboratory as well as its derivatives ${ }^{26}$. Hence, revisiting the potential use of known small molecules such as this one, at least as anti-amoebic agents, seems to be a good option in this field for drug discovery purposes. 

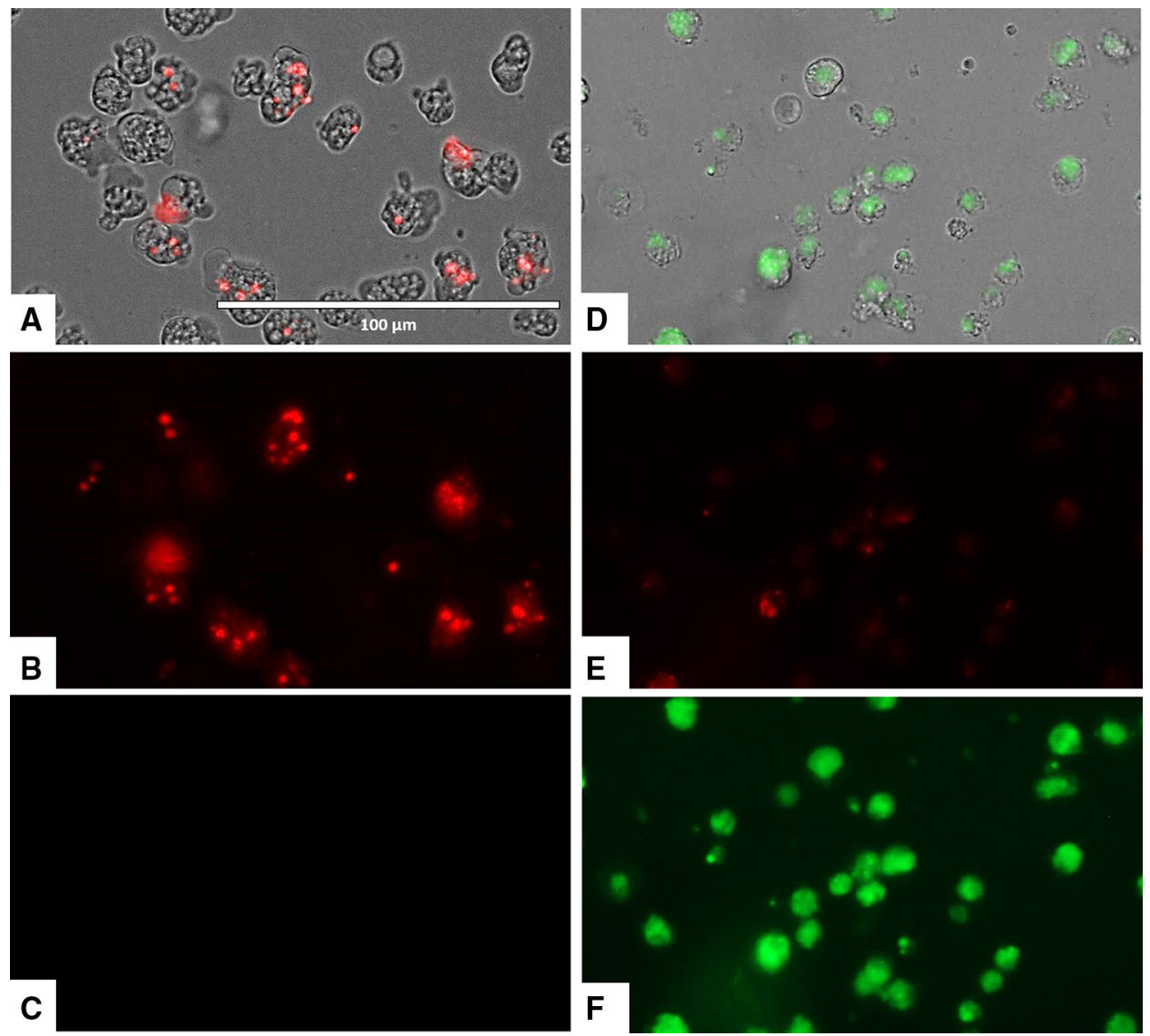

Figure 8. The effect of laurinterol (1) on the mitochondrial potential, JC-1 dye accumulates in the mitochondria of healthy cells as aggregates and emit a red fluorescence (A-C: Negative control). Cells treated with the $\mathrm{IC}_{90}$ of laurinterol (1) for $24 \mathrm{~h}$, emit green fluorescence (D-F): due to the decrease in mitochondrial membrane potential, the JC- 1 dye remained in the cytoplasm in its monomeric form and emit in this case a green fluorescence. (Images are representative of the population of treated cells $40 \times$ ). Images were obtained using an EVOS FL Cell Imaging System AMF4300, Life Technologies, Madrid, Spain.

Programmed Cell Death (PCD) and apoptosis-like processes have been previously described in protozoa and in multicellular organisms ${ }^{27}$. The phenomenom of PCD involves morphological and cellular events being the most commonly described ones: chromatin condensation, nuclear DNA fragmentation, cell shrinkage, blebbing, loss of mitochondrial membrane potential, the formation of apoptotic bodies, and the exposure of phosphatidylserine among others ${ }^{28,29}$.

In Naegleria genus, PCD events in treated cells with amphotericin B were described by Cardenas-Zuñiga and colleagues for the first time ${ }^{30}$. In this study, the effect of a non-lytic dose of amphotericin B $(10 \mu \mathrm{g} / \mathrm{ml})$ was evaluated in cultures of N. fowleri and N. gruberi. Among the observed events indicative of PCD, authors reported the presence of blebs, DNA condensation, ROS presence and electron-dense granules ${ }^{30}$.

For the development of novel therapeutic agents, our laboratory has focused on the evaluation of compounds of diverse origin but which are also inducers of PCD/apoptosis-like events, avoiding those molecules that induce necrosis and, hence, inflammation which is a non desirable side effect in the search of antiamoebic agents. In the present study, laurinterol was shown to induce chromatin condensation, plasma membrane damage, mitochondrial disfunction as well as increased levels of ROS. Since these effects were observed even after $24 \mathrm{~h}$ time of incubation with laurinterol, we postulate that this molecule could induce apoptosis in Naegleria through the intrinsic pathway since the mitochondrial potential was collapsed even at $24 \mathrm{~h}$, as well as ATP level (Figs. 7, 8). PCD is also indicated by the generation of ROS species and condensation of DNA. Moreover, when the macrophage cell line was incubated to laurinterol $\mathrm{IC}_{90}$ for $24 \mathrm{~h}$, no signs of PCD events were observed (data not shown). Hence, the observed PCD inductions effects are exclusively induced by this compound in N. fowleri.

In addition, the exact mechanism of action of laurinterol in Naegleria fowleri still needs further studies to be fully elucidated. Nevertheless, laurinterol has been reported as an inhibitor of Acetylcholinesterases (AChE) $)^{31}$. These enzymes play a key role in the human body since they catalyze the breakdown of acetylcholine and of some other choline esters that function as neurotransmitters ${ }^{32}$. In protists, AchE have been postulated to act as biomediators and their action is used by protozoa in processes such as cell to cell communications, reproduction, adhesion or motility. The recently reported genome project data for Naegleria fowleri and Naegleria gruberi species $^{33,34}$ have made available sequences in the databases (i.e. https://www.uniprot.org/uniprot/D2V1M1) which 


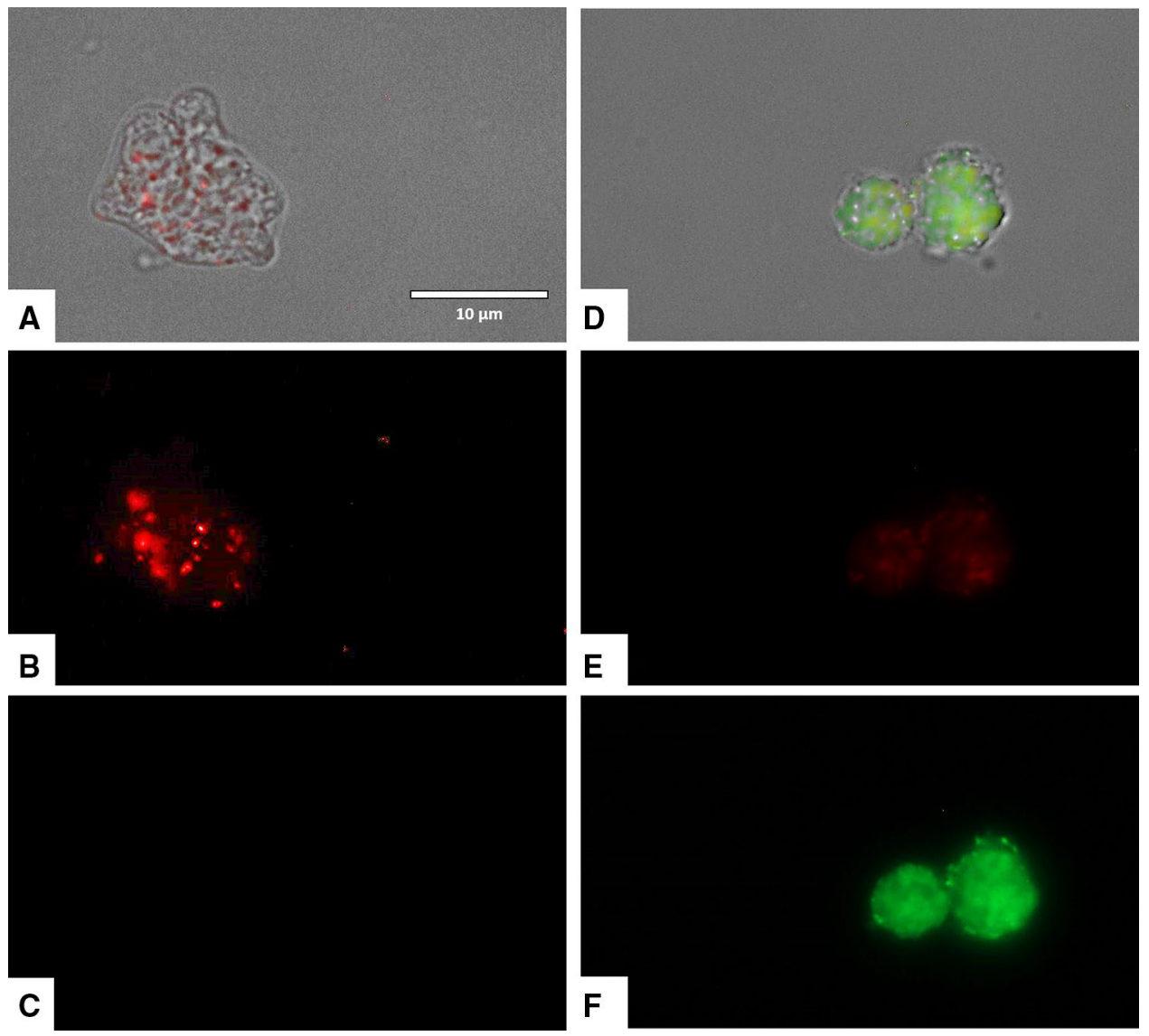

Figure 9. Higher magnification of Fig. $8(100 \times)$. Images were obtained using an EVOS FL Cell Imaging System AMF4300, Life Technologies, Madrid, Spain.
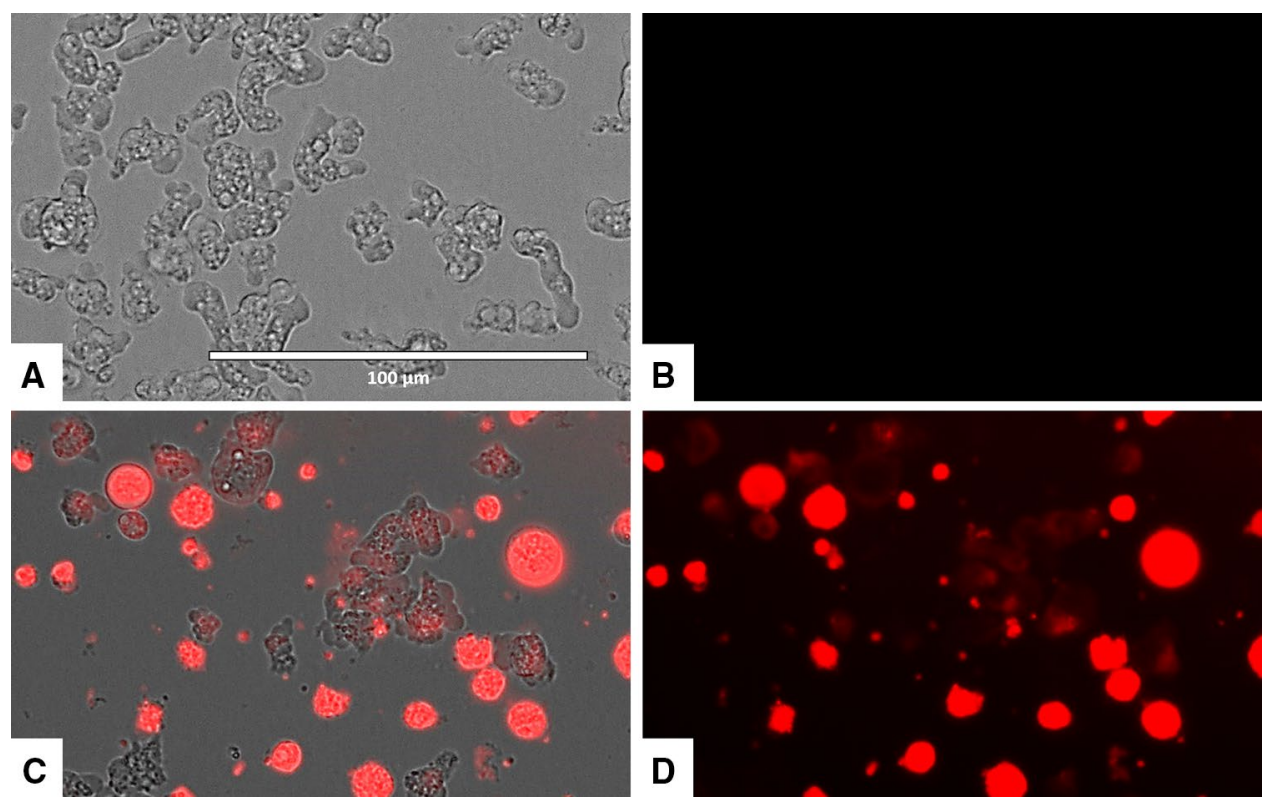

Figure 10. Increase levels of ROS in Naegleria fowleri caused by addition of laurinterol (1) at $\mathrm{IC}_{90}$ after $24 \mathrm{~h}$ $(\mathbf{C , D})$. Laurinterol (1) was added to cells $\left(10^{5}\right.$ cells $\left./ \mathrm{mL}\right)$ and exposed to CellROX Deep Red (5 $\left.\mu \mathrm{M}, 30 \mathrm{~min}\right)$ at $37^{\circ} \mathrm{C}$ in the dark. Negative Control (A,B): cells exposed to CellROX Deep Red in absence of laurinterol (1). Images $(40 \times)$ are representative of the cell population observed in the performed experiments. Images were obtained using an EVOS FL Cell Imaging System AMF4300, Life Technologies, Madrid, Spain. 

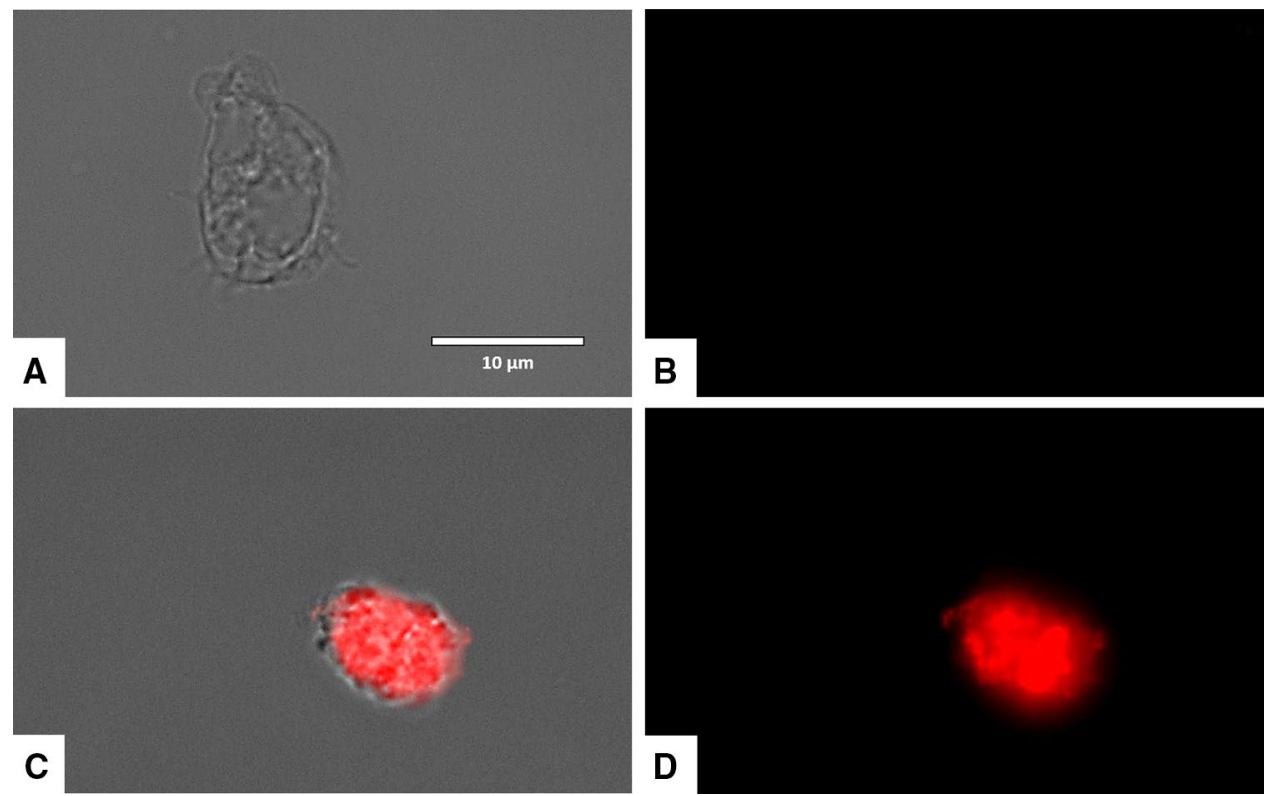

Figure 11. Higher magnification of Fig. $9(100 \times)$. Negative control $(\mathbf{A}, \mathbf{B})$. cells treated with the $\mathrm{IC}_{90}$ of laurinterol (1) for $24 \mathrm{~h}$. Images were obtained using an EVOS FL Cell Imaging System AMF4300, Life Technologies, Madrid, Spain.

are compatible to AchE-like enzymes. Therefore, the inactivation of these enzymes could trigger a cascade of events which could be the key to understand the observed morphological changes and PCD related events.

Previous reports indicate that phenolic sequiterpenes laurinterol and debromolaurinterol (2) showed inhibitory activity of ouabanin-sensitive dog kidney $\mathrm{P}$ Type $\mathrm{Na}^{+}, \mathrm{K}^{+}$-ATPase at $\mathrm{IC}_{50}$ of 40 and $400 \mu \mathrm{M}^{35,36}$. In addition, laurinterol exhibited induction of apoptosis by DNA fragmentation and activation of several caspases in melanoma cells. It was also demonstrated the transcriptional activation of the tumor suppressor gene p53 and the activation of $\mathrm{p} 21$ promoter. These studies indicate that laurinterol can induce apoptosis in melanoma cells through a p53-dependent pathway ${ }^{37}$.

The metabolic and histopathological effects of laurinterol on Vero and MCF-7 cell lines to breast cancer explants have been evaluated. A dose-dependent inhibition of the metabolic activity was observed, as well as morphologic and nuclear changes indicative of an apoptotic process. Cultures of human breast cancer explants treated with laurinterol showed a heterogeneous response, probably related with the individual response of each tumor sample. The study supports the cytotoxic and antitumoral effects of $\mathbf{1}$ both in in vitro cell cultures as in ex vivo organotypic cultures ${ }^{25}$.

On the other hand, allolaurinterol (4) (Fig. 1), another phenolic sequiterpene closely related to laurinterol, exhibited inhibition of eIF4A ATPase at low $\mu \mathrm{M}$ concentration. The enzymological study revealed that $\mathbf{4}$ is an ATP-competitive molecule $\left(\mathrm{K}_{\mathrm{i}} 3.86 \mu \mathrm{M}\right)$, whereas cellular evaluations showed reasonable cytotoxicity against lung cancer A549 and breast cancer MDA-MA-468 cell lines. The compound also showed potent inhibition of helicase activity consistent with its ATPase inhibitory activity with complete inhibition at $100 \mu \mathrm{M}$. Thus, this data proved that allolaurienterol is an ATP-competitive molecule most likely binding to the ATP-binding pocket at the interface between the $\mathrm{N}$-terminal and $\mathrm{C}$-terminal domains ${ }^{38,39}$.

In cells, $\mathrm{Na}^{+}, \mathrm{K}^{+}$-ATPase and $\mathrm{H}^{+}$-ATPase, two P-type ATPases, are essential to control homeostatic processes. A third P-type ATPase, the $\mathrm{K}+$ or $\mathrm{Na}+$ efflux ATPase (ENA ATPase), was discovered and, for many years, it was considered to be exclusively a fungal enzyme. ENA ATPase is now known to be also present in bryophytes and protozoa ${ }^{40-43}$. In protozoa, the presence of a ouabain-insensitive $\mathrm{Na}^{+}$-ATPase activity was found in Trypanosoma cruzi epimastigotes, stimulated by $\mathrm{Na}^{+}$, and inhibited by furosemide ${ }^{41}$. The fact that the ENA ATPase is found in almost all fungi, as well as in bryophytes and protozoa has been suggested to be an adaptive mechanism required in these organisms to prevail in certain life conditions. ENA genes found in the genome of the amoeba-flagellate Naegleria gruberi also point out the presence of ouabain-insensitive $\mathrm{Na}^{+}$-ATPase in this species. The structural characteristics of the ENA ATPase revealed that it maintains highly conserved sequences that are characteristic of P-type ATPases, such as the catalytic site, sequences involved in the nucleotide and $\mathrm{Mg}^{2+}$ binding, and others that are specific to ENA ATPases. N. gruberi shows the presence of the P type ATPase ouabain-insensitive and sensitive to furosemide identifying an ENA ATPase in the control of $\mathrm{Na}^{+43}$. The obtained results revealed that the $\mathrm{Na}^{+}$-ATPase ion pump of $N$. fowleri was ouabain-insensitive but sensitive to furosemide at concentrations of $0.71 \pm 0.04 \mathrm{mM}$ as mentioned in the "Results" section. Moreover, these data suggest that laurinterol $\left(\mathrm{IC}_{50}\right.$ of $13,42 \pm 2.57 \mu \mathrm{M})$ was able to inhibit this pump at concentrations 100 times lower than furosemide.

Thus, due to the highly conserved sequences in the nucleotide binding pocket of this specific P-Type ATPase, a competitive inhibition by phenolic sequiterpenes such as laurinterol could explain all the observed effects in N. fowleri (Fig. 12). 


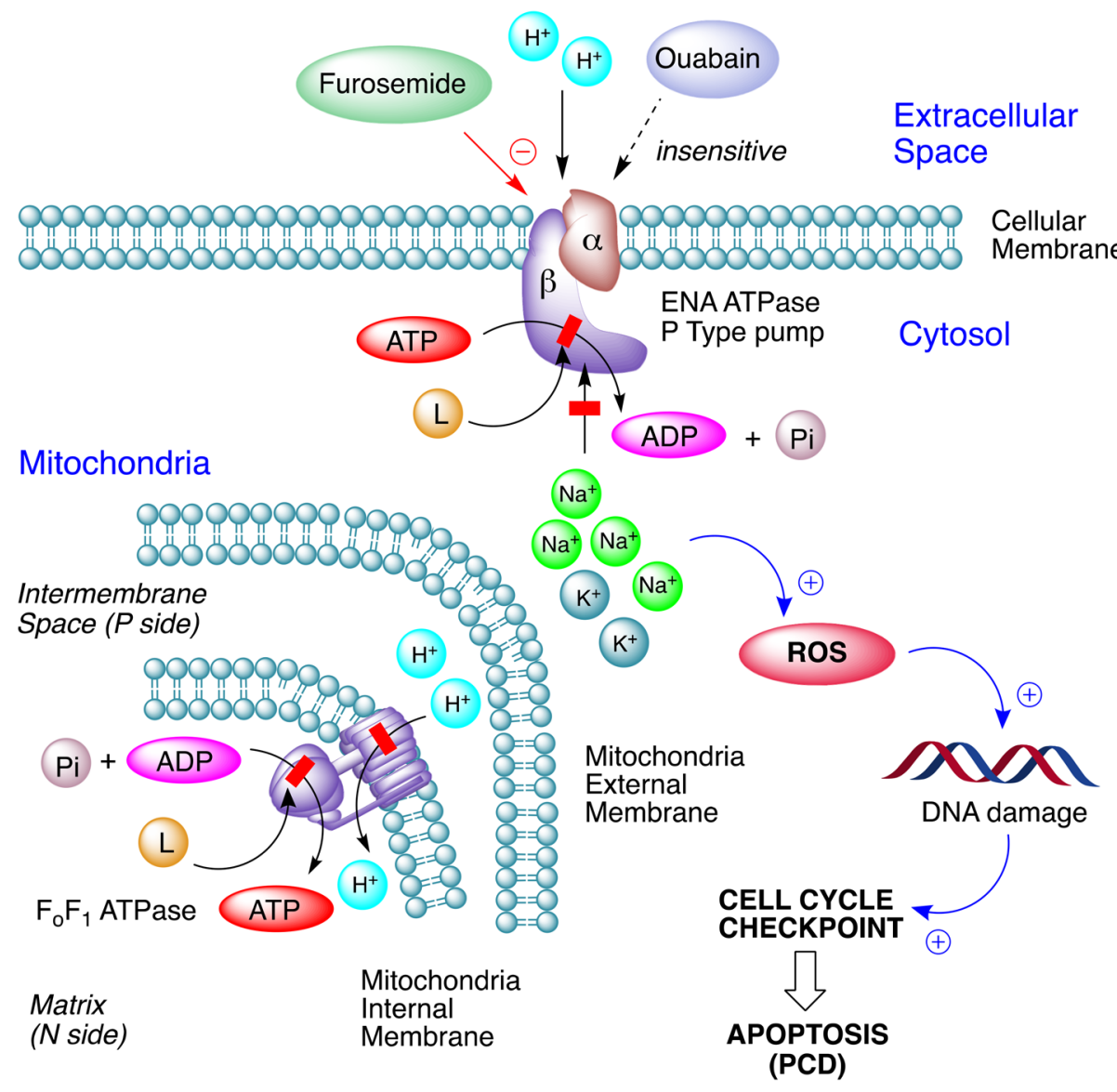

Figure 12. Proposed mechanism of action of laurinterol (1) as an ATP competitive inhibitor of P-type ATPases in Naegleria fowleri. L represents laurinterol (1).<smiles>Cc1c(Br)cc(C2(C)CCCC2(C)C)c(O)c1-c1c(C)c(Br)cc([C@]2(C)CCC[C@@H]2C)c1O</smiles>

5

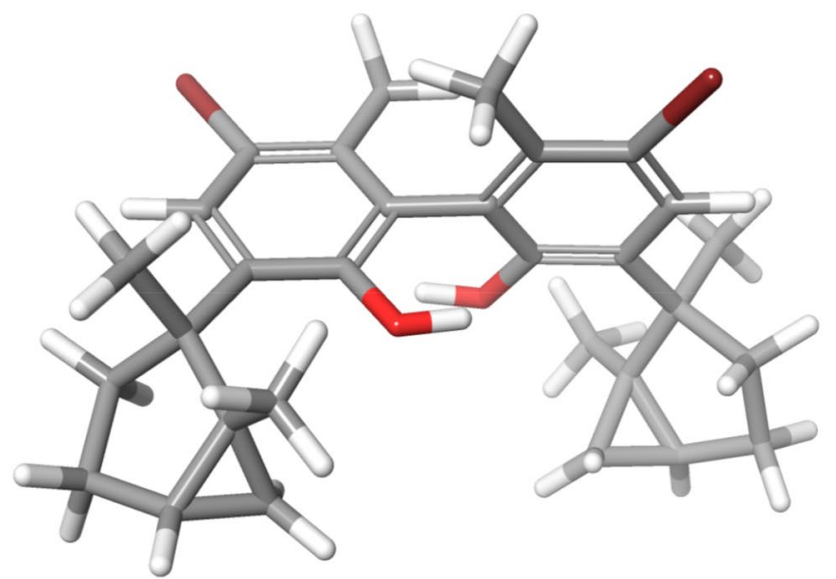

Figure 13. Structure and absolute configuration of laurinterol dimer (5) determined by X-ray crystallography.

Thus, an inhibition of sodium efflux ATPase would cause an increase in intracellular sodium concentration, which will trigger ROS, DNA damage and, hence, apoptosis ${ }^{44-46}$. At the level of cell organelles such as mitochondria, a plausible inhibition of FoF1 ATPase would cause a considerable decrease of ATP and strong changes in depolarization of the mitochondrial membrane ${ }^{47}$. All these effects caused by laurinterol in N. fowleri are consistent with a competitive, and not very specific, inhibition of ATPases. This assumption is based on the fact that laurinterol dimer (5) (Fig. 13) does not show activity $\left(\mathrm{IC}_{50}>100 \mu \mathrm{M}\right.$ ), possibly due to the increasement in volume of the molecule, which may limit the capacity to interact with the ATPases nucleotide binding pocket $^{38,39,43}$. Nevertheless, further studies to evaluate this drug target as well as SARs approaches should be developed in the near future. 


\section{Conclusion}

In conclusion, laurinterol showed a high activity against Naegleria fowleri trophozoites. Moreover, laurinteroltreated amoebae showed signs of PCD as shown by DNA condensation, damages in cell membrane and mitochondria and ROS generation triggered by a possible inhibition of ENA ATPase ion pump. Therefore, laurinterol is presented as a novel, highly active, PCD inducer and low toxic anti-Naegleria compound which should be exploited for the development of novel therapeutic agents against PAM.

\section{Methods}

Collection and identification of Laurencia johhstonii. Laurencia johnstonii was collected by hand off the coast of Baja California Sur, Mexico (24 21' 10.8" north (N), 110 $16^{\prime} 58.8^{\prime \prime}$ west (W)). A voucher specimen (code 13-003) was deposited at the Herbarium of the Laboratory of Marine Algae of the Interdisciplinary Center of Marine Science (CICIMAR) and it was identified by Dr. R. Riosmena Rodríguez from the Autonomous University of Baja California Sur (UABCS).

Extraction and isolation of laurinterol (1), debromolaurinterol (2) and isolaurinterol (3). Washed and dried specimens of L. johnstonii were crushed and extracted with EtOH for three days at $25^{\circ} \mathrm{C}$. Dissolvent was replaced three times, the combined extracts were filtered through a Whatman no. 4 filter paper and concentrated under vacuum. The resulting extract was chromatographed in Sephadex LH-20 $\left(500 \times 70 \mathrm{~mm}, \mathrm{CH}_{3} \mathrm{OH}, 100 \%\right)$ to obtain five fractions. The active fraction SF3 was separated in Flash silica gel $(130 \times 70 \mathrm{~mm})$ using a stepwise gradient from $n$-hexane to ethyl acetate to obtain seven fractions. The active fraction SF3.2 (95\% $n$-hexane) was chromatographed on a normal phase open column $(300 \times 50 \mathrm{~mm})$ using a stepwise gradient from $n$-hexane to ethyl acetate to yield pure compounds 1, 2 and 3.

Laurinterol (1). White crystal; $[\alpha]^{25}{ }_{\mathrm{D}}+17\left(c 0.15, \mathrm{CH}_{2} \mathrm{Cl}_{2}\right)$; HRESIMS m/z 293.0531 [M-H $]^{-}\left(\right.$calc. $\mathrm{C}_{15} \mathrm{H}_{18} \mathrm{O}^{79} \mathrm{Br}$, 293.0541), $295.0518[\mathrm{M}-\mathrm{H}]^{-}\left(\right.$calc. $\left.\mathrm{C}_{15} \mathrm{H}_{18} \mathrm{O}^{81} \mathrm{Br}, 295.0521\right){ }^{1} \mathrm{H} \mathrm{NMR}\left(500 \mathrm{MHz}, \mathrm{CDCl}_{3}\right) \delta 0.55(1 \mathrm{H}, \mathrm{dd}, J=7.9$, $4.8 \mathrm{~Hz}, \mathrm{H}-12), 0.58(1 \mathrm{H}, \mathrm{t}, J=4.6 \mathrm{~Hz}, \mathrm{H}-12), 1.15(1 \mathrm{H}, \mathrm{dt}, J=8.1,4.3 \mathrm{~Hz}, \mathrm{H}-3), 1.28(1 \mathrm{H}, \mathrm{m}, \mathrm{H}-5), 1.32(3 \mathrm{H}, \mathrm{s}$, $\mathrm{H}-13), 1.41$ (3H, s, H-14), 1.66 (1H, dd, $J=12.3,8.0 \mathrm{~Hz}, \mathrm{H}-4), 1.95$ (1H, tdd, $J=12.3,8.1,4.4, \mathrm{H}-4), 2.09$ (1H, dd, $J=13.2,8.1 \mathrm{~Hz}, \mathrm{H}-5), 2.29(3 \mathrm{H}, \mathrm{s}, \mathrm{H}-15), 5.26(1 \mathrm{H}, \mathrm{br}, \mathrm{s}, 7-\mathrm{OH}), 6,61(1 \mathrm{H}, \mathrm{s}, \mathrm{H}-8), 7.61(1 \mathrm{H}, \mathrm{s}, \mathrm{H}-11) ;{ }^{13} \mathrm{C}$ NMR $\left(125 \mathrm{MHz}, \mathrm{CDCl}_{3}\right) \delta 16.2$ (C-12), 18.6 (C-13), 22.2 (C-14), 23.5 (C-15), 24.4 (C-3), 25.3 (C-4), 29.6 (C-2), 35.9 (C-5), 114.9 (C-10), 118.8 (C-8), 132.3 (C-11), 134.0 (C-6), 135.9 (C-9), 153.3 (C-7).

Debromolaurinterol (2). Colorless amorphous solid; $[\alpha]^{25}-6.35$ (c $0.19, \mathrm{CH}_{2} \mathrm{Cl}_{2}$ ); HRESIMS $\mathrm{m} / z 215.1432$ $[\mathrm{M}-\mathrm{H}]^{-}\left(\right.$calc. $\left.\mathrm{C}_{15} \mathrm{H}_{19} \mathrm{O}, 215.1436\right){ }^{1} \mathrm{H}$ NMR $\left(500 \mathrm{MHz}, \mathrm{CDCl}_{3}\right) \delta 0.52(1 \mathrm{H}, \mathrm{dd}, J=7.8,4.4 \mathrm{~Hz}, \mathrm{H}-12), 0.59(1 \mathrm{H}$, t, $J=4.4 \mathrm{~Hz}, \mathrm{H}-12), 0.91(1 \mathrm{H}, \mathrm{m}, \mathrm{H}-3), 1.13(1 \mathrm{H}, \mathrm{dt}, J=8.2,4.1 \mathrm{~Hz}, \mathrm{H}-5), 1.33(3 \mathrm{H}, \mathrm{s}, \mathrm{H}-13), 1.43(3 \mathrm{H}, \mathrm{s}, \mathrm{H}-14)$, $1.66(1 \mathrm{H}, \mathrm{dd}, J=13.1,8.4 \mathrm{~Hz}, \mathrm{H}-4), 1.96(1 \mathrm{H}$, dddd, $J=12.3,12.3,8.0,4.3 \mathrm{~Hz}, \mathrm{H}-4), 2.13(1 \mathrm{H}, \mathrm{dd}, J=13.1,7.8 \mathrm{~Hz}$, H-5), 2.28 (3H, s, H-15), $5.17(1 \mathrm{H}, \mathrm{s}, 7-\mathrm{OH}), 6.56(1 \mathrm{H}, \mathrm{d}, J=1.6 \mathrm{~Hz}, \mathrm{H}-8), 6.70(1 \mathrm{H}, \mathrm{dd}, J=7.9,1.6 \mathrm{~Hz}, \mathrm{H}-10)$, $7.39(1 \mathrm{H}, \mathrm{d}, J=7.9 \mathrm{~Hz}, \mathrm{H}-11) ;{ }^{13} \mathrm{C}$ NMR $\left(125 \mathrm{MHz}, \mathrm{CDCl}_{3}\right) \delta 16.3(\mathrm{C}-12), 18.8(\mathrm{C}-13), 20.6(\mathrm{C}-14), 23.6(\mathrm{C}-15)$, 24.3 (C-3), 25.3 (C-4), 27.7 (C-2), 36.0 (C-5), 48.0 (C-1), 117.3 (C-10), 120.8 (C-8), 128.8 (C-11), 131.4 (C-6), 136.7 (C-9), $154.0(\mathrm{C}-7)$.

Isolaurinterol (3). Colorless amorphous solid; [a $]^{25}$ - 46 (c 0.14, $\left.\mathrm{CH}_{2} \mathrm{Cl}_{2}\right)$; HRESIMS m/z 293.0536 [M-H] ${ }^{-}$ (calc. $\left.\mathrm{C}_{15} \mathrm{H}_{18} \mathrm{O}^{79} \mathrm{Br}, 293.0541\right), 295.0528[\mathrm{M}-\mathrm{H}]^{-}\left(\right.$calc. $\left.\mathrm{C}_{15} \mathrm{H}_{18} \mathrm{O}^{81} \mathrm{Br}, 295.0521\right){ }^{1} \mathrm{H}$ NMR $\left(500 \mathrm{MHz}, \mathrm{CDCl}_{3}\right) \delta$ $1.21(3 \mathrm{H}, \mathrm{d}, J=7.0 \mathrm{~Hz}, \mathrm{H}-12), 1.42(1 \mathrm{H}, \mathrm{ddd}, J=12.8,8.2,6.6 \mathrm{~Hz}, \mathrm{H}-5), 1.46$ (3H, s, H-14), $1.59(1 \mathrm{H}, \mathrm{dt}, J=12.9$, 7.1, 7.1 Hz, H-4), 2.05 (1H, ddt $J=12.8,8.5,7.0,7.0 \mathrm{~Hz}, \mathrm{H}-3), 2.20(1 \mathrm{H}, \mathrm{ddd}, J=13.0,8.16 .7 \mathrm{~Hz}, \mathrm{H}-4), 2.31(3 \mathrm{H}$, s, H-15), $2.85(1 \mathrm{H}$, ddt, $J=9.1,6.9,6.9,2.3,2.3 \mathrm{~Hz}, \mathrm{H}-5), 4.94(1 \mathrm{H}, \mathrm{d}, J=2.2 \mathrm{~Hz}, \mathrm{H}-13), 5.11(1 \mathrm{H}, \mathrm{d}, J=2.2 \mathrm{~Hz}$, $\mathrm{H}-13), 5.56(1 \mathrm{H}, \mathrm{br}, \mathrm{s}, 7-\mathrm{OH}), 6.73(1 \mathrm{H}, \mathrm{s}, \mathrm{H}-8), 7.45(1 \mathrm{H}, \mathrm{s}, \mathrm{H}-11) ;{ }^{13} \mathrm{C} \mathrm{NMR}\left(125 \mathrm{MHz}, \mathrm{CDCl}_{3}\right) \delta 21.2(\mathrm{C}-14)$, 22.2 (C-15), 27.8 (C-12), 31.2 (C-4), 37.6 (C-3), 39.1 (C-5), 49.8 (C-1), 106.9 (C-13), 115.5 (C-10), 120.4 (C-8), 131.2 (C-11), 132.7 (C-6), 137.2 (C-9), 153.0 (C-7), 165.4 (C-2).

Synthesis of laurinterol dimer (5). Laurinterol dimer (5) was obtained by oxidation of laurinterol according to Ichiba and Higa (1986) with some modifications. Briefly, 1 (50 mg) was dissolved in $80 \%$ acetic acid $(1 \mathrm{~mL})$ and $200 \mu \mathrm{L}$ of $25 \%$ chromium trioxide solution in acetic acid was added. The reaction was left under magnetic stirring for $2 \mathrm{~h}$ at $4{ }^{\circ} \mathrm{C}$ and extracted with dichloromethane after addition of water. The reaction mixture was separated on a normal phase open column (Silicagel, $0.2-0.5 \mathrm{~mm}, 30 \varnothing \times 110 \mathrm{~mm}$ ) eluted with $n$-Hex/ EtOAc (99:1) to obtain 7 fractions. Fraction 2 was purified by HPLC on a normal phase column (Luna $5 \mu \mathrm{m}$ Silica $100 \AA$, $10 \varnothing \times 250 \mathrm{~mm}$ ) eluted with $n$-Hex/EtOAc (99:1) to yield 5, (2 mg).

Laurinterol dimer (5). White crystal; $[\alpha]^{25}{ }_{\mathrm{D}}-32.5\left(c 0.04, \mathrm{CH}_{2} \mathrm{Cl}_{2}\right.$ ); HRESIMS $m / z 585.1000[\mathrm{M}-\mathrm{H}]^{-}$(calc. $\mathrm{C}_{30} \mathrm{H}_{35} \mathrm{O}_{2}{ }^{79} \mathrm{Br}_{2}, 293.0541$ ), 587.0981 [M-H] ${ }^{-}$(calc. $\mathrm{C}_{30} \mathrm{H}_{35} \mathrm{O}_{2}{ }^{79} \mathrm{Br}^{81} \mathrm{Br}, 587.0983$ ), 589.0951 [M- $\mathrm{M}^{-}$(calc. $\left.\mathrm{C}_{30} \mathrm{H}_{35} \mathrm{O}_{2}{ }^{81} \mathrm{Br}_{2}, 589.0963\right) ;{ }^{1} \mathrm{H}$ NMR $\left(500 \mathrm{MHz}, \mathrm{CDCl}_{3}\right) \delta 0.54(1 \mathrm{H}, \mathrm{d}, J=5.3 \mathrm{~Hz}, \mathrm{H}-13), 0.57(1 \mathrm{H}, \mathrm{d}, J=5.1 \mathrm{~Hz}$, $\mathrm{H}-13), 1.11(1 \mathrm{H}, \mathrm{dt}, J=8.1,4.2 \mathrm{~Hz}, \mathrm{H}-3), 1.26(2 \mathrm{H}, \mathrm{m}, \mathrm{H}-5), 1.33(3 \mathrm{H}, \mathrm{s}, \mathrm{H}-12), 1.38(3 \mathrm{H}, \mathrm{s}, \mathrm{H}-14), 1.63(1 \mathrm{H}$, dd, $J=12.4,7.9 \mathrm{~Hz}, \mathrm{H}-4), 1.92(1 \mathrm{H}, \mathrm{m}, \mathrm{H}-4), 2.02(3 \mathrm{H}, \mathrm{s}, \mathrm{H}-15), 2.18(1 \mathrm{H}, \mathrm{m}, \mathrm{H}-5), 4.77(1 \mathrm{H}, \mathrm{br}, \mathrm{s}, 7-\mathrm{OH}), 7.83$ $(1 \mathrm{H}, \mathrm{s}, \mathrm{H}-11) ;{ }^{13} \mathrm{C}$ NMR $\left(500 \mathrm{MHz}, \mathrm{CDCl}_{3}\right) \delta 16.3$ (C-13), 18.9 (C-12), 19.9 (C-15), 22.5 (C-14), 24.3 (C-3), 25.4 (C-4), 29.7 (C-2), 35.5 (C-5), 48.7 (C-1), 115.9 (C-10), 122.0 (C-8), 133.3 (C-11), 135.1 (C-9), 135.6 (C-6), 152.1 (C-7). NMR data are in accordance with those previously reported for the natural compound ${ }^{49}$. X-Ray crystallographic data of 5 is reported for the first time (Supplementary material S1). CCDC 2036372 contains the supplementary crystallographic data for this paper. These data can be obtained free of charge from The Cambridge Crystallographic Data Centre via www.ccdc.cam.ac.uk/structures ${ }^{50}$. 
Commercial ATPase ion pump inhibitors. Ouabain octahydrate (CAS no. 11018-89-6) and furosemide (CAS no. 54-31-9) were acquired from Sigma-Aldrich.

In vitro amoebicidal and cytotoxicity assays. Naegleria fowleri strain. A type strain of Naegleria fowleri with reference number ATCC 30808 from the American Type Culture Collection (LG Promochem, Barcelona, Spain) was used in this study. The strain was axenically cultured at $37{ }^{\circ} \mathrm{C}$ in $2 \%(\mathrm{w} / \mathrm{v})$ Bactocasitone medium (Thermo Fisher Scientific, Madrid, Spain) supplemented with 10\% (v/v) foetal bovine serum (FBS), containing $0,5 \mathrm{mg} / \mathrm{ml}$ of Streptomycin sulfate (Sigma-Aldrich, Madrid, Spain) and $0.3 \mu \mathrm{g} / \mathrm{ml}$ of Penicillin G Sodium Salt (Sigma-Aldrich, Madrid, Spain). The strains were cultured in a biological security facility of level 3 at our institution following Spanish biosafety guidelines for this pathogen.

In vitro activity assays against the trophozoite stage of Naegleria fowleri. The activities of the tested compounds against Naegleria fowleri trophozoites were determined using a colorimetric assay as previously described ${ }^{9}$. Briefly, Naegleria trophozites were seeded in duplicate on a 96-well microtiter plate with $50 \mu \mathrm{L}$ from a stock solution of $2 \times 10^{5} \mathrm{cells} / \mathrm{ml}$. After that, a serial dilution of the evaluated compounds (in the same culture medium as the amoeba) was added to the plate. A negative control in the plates, consisted in amoebae in medium alone. Finally, the AlamarBlue reagent (Life Technologies, Madrid, Spain) was placed in each well ( $10 \%$ of medium volume) and plates were incubated with slight agitation for $48 \mathrm{~h}$ at $37^{\circ} \mathrm{C}$. After that, plates were analysed with an EnSpire Multimode Plate Reader (Perkin Elmer, Madrid, Spain) using a wavelength of excitation of $570 \mathrm{~nm}$ and a wavelength of emission of $585 \mathrm{~nm}$. To calculate the percentages of growth inhibition and the $50 \%$ and $90 \%$ inhibitory concentrations $\left(\mathrm{IC}_{50}\right.$ and $\left.\mathrm{IC}_{90}\right)$ a no linear regression analysis was performed with a 95\% confidence limit using the SigmaPlot 12.0 software (Systat Software Inc.,London, UK). Experiments were performed in triplicated and the mean values were also calculated. A paired two-tailed $t$-test was used for the analysis of the data and the values of $\mathrm{P}<0.05$ were considered statistically significant. In all assays, $1 \%$ DMSO was used to dissolve the highest dose of the compounds. When 1\% DMSO was added to medium alone (without any investigated compound) no effect was observed on the amoebae.

Cytotoxicity assays. Cytotoxicity of laurinterol (the most active tested compound) was evaluated after $24 \mathrm{~h}$ incubation of a murine macrophage J774.A1 cell line (ATCC \# TIB-67) with different concentration of the tested compound at $37{ }^{\circ} \mathrm{C}$ in a $5 \% \mathrm{CO}_{2}$ humidified incubator as previously described ${ }^{51}$.

Double-stain assay for programmed cell death determination. A double-stain apoptosis detection kit (Hoechst 33342/PI) (Life Technologies, Madrid, Spain) and an EVOS FL Cell Imaging System AMF4300, (Life Technologies, Madrid, Spain) were used in this assay. The experiment was carried out by following the manufacturer's recommendations, and $5 \times 10^{5}$ cells $/ \mathrm{ml}$ well were incubated in a 96-well plate for $24 \mathrm{~h}$ with the previously calculated $\mathrm{IC}_{90}$. As it has been previously reported ${ }^{52}$, the double-staining pattern allows the identification of three groups in a cellular population: live cells will show only a low level of fluorescence, cells undergoing PCD will show a higher level of blue fluorescence (as chromatin condenses), and dead cells will show low-blue and high-red fluorescence (as the Propidium Iodide stain enters the nucleus).

CellROX deep red staining. The generation of intracellular ROS was evaluated by using the CellROX Deep Red fluorescent probe (Invitrogen, Termo Fisher Scientific, Madrid, Spain). Naegleria fowleri trophozoites were treated with the $\mathrm{IC}_{90}$ of laurinterol for $24 \mathrm{~h}$ and exposed to CellROX Deep Red $(5 \mu \mathrm{M}, 30 \mathrm{~min})$ at $37^{\circ} \mathrm{C}$ in the dark. Cells were observed in an EVOS FL Cell Imaging System AMF4300 (Life Technologies, Madrid, Spain).

Analysis of mitochondrial function disruption. Mitochondrial membrane potential. The collapse of an electrochemical gradient across the mitochondrial membrane during PCD induction in treated amoebae was detected with the JC-1 mitochondrial membrane potential detection kit (Cayman Chemicals, Vitro SA, Madrid, Spain). Amoebae were incubated with the $\mathrm{IC}_{90}$ of laurinterol for $24 \mathrm{~h}$ and the experiment was carried out by following the manufacturer's recommendations. Images were captured using an EVOS FL Cell Imaging System AMF4300, Life Technologies, Madrid, Spain. The obtained staining pattern allowed the identification of two groups in a cellular population: live cells will show only red fluorescence; cells with low mitochondrial potential, (undergoing PCD) will show a higher level of green and red fluorescence.

ATP levels. ATP levels were measured using a CellTiter-Glo Luminescent Cell Viability Assay (PROMEGA BIOTECH IBÉRICA S.L, Madrid, Spain). The effect of the drug on the ATP production was evaluated by incubating $5 \times 10^{5}$ cells $/ \mathrm{ml}$ with the previously calculated $\mathrm{IC}_{90}$ of laurinterol.

Plasma membrane permeability. The SYTOX Green assay was performed to detect alterations of the membrane permeability in treated cells. Briefly, $5 \times 10^{5}$ trophozoites were incubated with the previously calculated $\mathrm{IC}_{90}$ of laurinterol. After $24 \mathrm{~h}$ of incubation, the SYTOX Green was added at a final concentration of $1 \mu \mathrm{M}$ (Molecular Probes). Cells were observed after $15 \mathrm{~min}$ in an EVOS FL Cell Imaging System AMF4300 (Life Technologies, Madrid, Spain). 
Received: 3 April 2020; Accepted: 30 September 2020

Published online: 20 October 2020

\section{References}

1. Cope, J. R. \& Ali, I. K. Primary amebic meningoencephalitis: what have we learned in the last 5 years?. Curr. Infect. Dis. Rep. 18, 31. https://doi.org/10.1007/s11908-016-0539-4 (2016).

2. Betanzos, A., Bañuelos, C. \& Orozco, E. Host invasion by pathogenic amoebae: epithelial disruption by parasite proteins. Genes. 10, 618. https://doi.org/10.3390/genes10080618 (2019).

3. Lopez, C. et al. Primary amebic meningoencephalitis. Pediatr. Emerg. Care. 28, 272-276. https://doi.org/10.1097/pec.0b013e3182 495589 (2012)

4. Maciver, S. K., Piñero, J. E. \& Lorenzo-Morales, J. Is Naegleria fowleri an emerging parasite?. Trends Parasitol. 36, 19-28. https:// doi.org/10.1016/j.pt.2019.10.008 (2020).

5. Fowler, M. \& Carter, R. F. Acute pyogenic meningitis probably due to Acanthamoeba sp.: a preliminary report. Br. Med. J. 2, 740-742. https://doi.org/10.1136/bmj.2.5464.734-a (1965).

6. Jahangeer, M. et al. Naegleria fowleri: Sources of infection, pathophysiology, diagnosis, and management; a review. Clin. Exp. Pharmacol. Physiol. 47, 199-212. https://doi.org/10.1111/1440-1681.13192 (2020).

7. Siddiqui, R., Ali, I. K. M., Cope, J. R. \& Khan, N. A. Biology and pathogenesis of Naegleria fowleri. Acta Trop. 164, 375-394. https ://doi.org/10.1016/j.actatropica.2016.09.009 (2016).

8. Trabelsi, H. et al. Pathogenic free-living amoebae: epidemiology and clinical review. Pathol. Biol. 60, 399-405. https://doi. org/10.1016/j.patbio.2012.03.002 (2012).

9. Rizo-Liendo, A. et al. In vitro activity of statins against Naegleria fowleri. Pathogens. 8, 122. https://doi.org/10.3390/pathogens8 $030122(2019)$.

10. Schuster, F. L. \& Visvesvara, G. S. Free-living amoebae as opportunistic and non-opportunistic pathogens of humans and animals. Int. J. Parasitol. 34, 1001-1027. https://doi.org/10.1016/j.ijpara.2004.06.004 (2004).

11. Capewell, L. G. et al. Diagnosis, clinical course, and treatment of primary amoebic meningoencephalitis in the United States, 1937-2013. J. Pediatric. Infect. Dis. Soc. 4, e68-75. https://doi.org/10.1093/jpids/piu103 (2015).

12. Grace, E., Asbill, S. \& Virga, K. Naegleria fowleri: pathogenesis, diagnosis, and treatment options. Antimicrob. Agents Chemother. 59, 6677-6681. https://doi.org/10.1128/AAC.01293-15 (2015).

13. Bellini, N. K. et al. The therapeutic strategies against Naegleria fowleri. Exp. Parasitol. 187, 1-11. https://doi.org/10.1016/j.exppa ra.2018.02.010 (2018).

14. Sood, A., Chauhan, S., Chandel, L. \& Jaryal, S. C. Prompt diagnosis and extraordinary survival from Naegleria fowleri meningitis: a rare case report. Indian J. Med. Microbiol. 32, 193-196. https://doi.org/10.4103/0255-0857.129834 (2014).

15. Linam, W. M. et al. Successful treatment of an adolescent with Naegleria fowleri primary amebic meningoencephalitis. Pediatrics 135, e744-e748. https://doi.org/10.1542/peds.2014-2292 (2015).

16. Heggie, T. W. \& Küpper, T. Surviving Naegleria fowleri infections: a successful case report and novel therapeutic approach. Travel Med. Infect. Dis. 16, 49-51. https://doi.org/10.1016/j.tmaid.2016.12.005 (2017).

17. Shen, B. A new golden age of natural products drug discovery. Cell 163, 1297-1300. https://doi.org/10.1016/j.cell.2015.11.031 (2015).

18. Laing, R., Gillan, V. \& Devaney, E. Ivermectin: old drug, new tricks?. Trends Parasitol. 33, 463-472. https://doi.org/10.1016/j. pt.2017.02.004 (2017).

19. Eyal, S. The fever tree: from malaria to neurological diseases. Toxins. 10, 491. https://doi.org/10.3390/toxins10120491 (2018).

20. García-Davis, S. et al. Anti-Acanthamoeba activity of brominated sesquiterpenes from Laurencia johnstonii. Mar. Drugs. 16, 443. https://doi.org/10.3390/md16110443 (2018).

21. Lorenzo-Morales, J. et al. Evaluation of oxasqualenoids from the red Alga Laurencia viridis against Acanthamoeba. Mar. Drugs. 17, 420. https://doi.org/10.3390/md17070420 (2019).

22. Mendiola, M. J. et al. Inhibiting activity of the in vitro growth of Plasmodium falciparum of extracts from algae of genus Laurencia. Rev. Cubana Med. Trop. 57, 192-195 (2005).

23. Da Silva Machado, F. L. et al. Antileishmanial sesquiterpenes from the Brazilian red alga Laurencia dendroidea. Planta Med. 77, 733-735. https://doi.org/10.1055/s-0030-1250526 (2011).

24. Díaz-Marrero, A. R. et al. Antiprotozoal activities of marine polyether triterpenoids. Bioorg. Chem. 92, 103276. https://doi. org/10.1016/j.bioorg.2019.103276 (2019).

25. García-Davis, S. et al. Antitumoral effect of laurinterol on 3D culture of breast cancer explants. Mar Drugs. 17, 201. https://doi. org/10.3390/md17040201 (2019).

26. Feutrill, G. I., Mirrington, R. N. \& Nichols, R. J. The total synthesis of ( \pm )-laurinterol and related compounds. Aust. J. Chem. 26, 345-355. https://doi.org/10.1071/CH9730345 (1973).

27. Kaczanowski, S., Sajid, M. \& Reece, S. E. Evolution of apoptosis-like programmed cell death in unicellular protozoan parasites. Parasit. Vect. 4, 44. https://doi.org/10.1186/1756-3305-4-44 (2011).

28. D’Arcy, M. S. Cell death: a review of the major forms of apoptosis, necrosis and autophagy. Cell Biol. Int. 43, 582-592. https://doi. org/10.1002/cbin.11137 (2019).

29. Sifaoui, I. et al. Programmed cell death in Acanthamoeba castellanii Neff induced by several molecules present in olive leaf extracts. PLoS ONE 12, e0183795. https://doi.org/10.1371/journal.pone.0183795 (2017).

30. Cárdenas-Zúñiga, R. et al. Amphotericin B induces apoptosis-like programmed cell death in Naegleria fowleri and Naegleria gruberi. Microbiology 163, 940-949. https://doi.org/10.1099/mic.0.000500 (2017).

31. Ishii, T., Nagamine, T., Nguyen, B. C. \& Tawata, S. Insecticidal and repellent activities of laurinterol from the Okinawan Red Alga Laurencia nidifica. Rec. Nat. Prod. 11, 63-68 (2017).

32. Leuzinger, W. Structure and function of acetylcholinesterase. Prog. Brain Res. 31, 241-245. https://doi.org/10.1016/S0079 $-6123(08) 63242-2(1969)$.

33. Mullican, J. C., Chapman, N. M. \& Tracy, S. Complete genome sequence of the circular extrachromosomal element of Naegleria gruberi strain EGB ribosomal DNA. Genome Announc. 6, e00020-e118. https://doi.org/10.1128/genomeA.00020-18 (2018).

34. Liechti, N. Nanopore sequencing improves the draft genome of the human pathogenic amoeba Naegleria fowleri. Sci. Rep. 9, 16040. https://doi.org/10.1038/s41598-019-52572-0 (2019).

35. Okamoto, Y., Nitanda, N., Ojika, M. \& Sakagami, Y. Aplysiallene, a new bromoallene as an Na, K-ATPase inhibitor from the sea hare, Aplysia kurodai. Biosci. Biotechnol. Biochem. 65, 474-476. https://doi.org/10.1271/bbb.65.474 (2001).

36. Okamoto, Y., Ojika, M., Kato, S. \& Sakagami, Y. Ianthesines A-D, four novel dibromotyrosine-derived metabolites from a marine mponge Ianthella sp.. Tetrahedron 56, 5813-5818. https://doi.org/10.1016/S0040-4020(00)00544-5 (2000).

37. Kim, M. M., Mendis, E. \& Kim, S. K. Laurencia okamurai extract containing laurinterol induces apoptosis in melanoma cells. J Med Food. 11, 260-266. https://doi.org/10.1089/jmf.2007.575 (2008).

38. Tillotson, J. et al. ATP-competitive, marine derived natural products that target the DEAD box helicase, eIF4A. Bioorg. Med. Chem. Lett. 27, 4082-4085. https://doi.org/10.1016/j.bmcl.2017.07.045 (2017). 
39. Schütz, P. et al. Crystal structure of the yeast eIF4A-eIF4G complex: an RNA-helicase controlled by protein-protein interactions. Proc. Natl. Acad. Sci. USA 105, 9564-9569. https://doi.org/10.1073/pnas.0800418105 (2008).

40. Studer, R. A., Person, E., Robinson-Rechavi, M. \& Rossier, B. C. Evolution of the epithelial sodium channel and the sodium pump as limiting factors of aldosterone action on sodium transport. Physiol. Genomics. 43, 844-854. https://doi.org/10.1152/physiolgen omics.00002.2011 (2011).

41. De Souza, A. M. et al. Entamoeba histolytica: ouabain-insensitive Na(+)-ATPase activity. Exp. Parasitol. 117, 195-200. https://doi. org/10.1016/j.exppara.2007.04.010 (2007).

42. Fraile-Escanciano, A., Garciadeblás, B., Rodríguez-Navarro, A. \& Benito, B. Role of ENA ATPase in $\mathrm{Na}(+)$ efflux at high pH in bryophytes. Plant Mol. Biol. 71, 599-608. https://doi.org/10.1007/s11103-009-9543-5 (2009).

43. Rodríguez-Navarro, A. \& Benito, B. Sodium or potassium efflux ATPase a fungal, bryophyte, and protozoal ATPase. Biochim Biophys Acta. 1798, 1841-1853. https://doi.org/10.1016/j.bbamem.2010.07.009 (2010).

44. Clausen, M. V., Hilbers, F. \& Poulsen, H. The structure and function of the Na, K-ATPase isoforms in health and disease. Front. Physiol. 8, 371. https://doi.org/10.3389/fphys.2017.00371 (2017).

45. Alharbi, Y. et al. Plumbagin-induced oxidative stress leads to inhibition of $\mathrm{Na}+/ \mathrm{K}+$-ATPase (NKA) in canine cancer cells. Sci. Rep. 9, 11471. https://doi.org/10.1038/s41598-019-47261-x (2019).

46. Felippe Gonçalves-de-Albuquerque, C., Ribeiro Silva, A., Ignácio da Silva, C., Caire Castro-Faria-Neto, H. \& Burth, P. Na/K pump and beyond: Na/K-ATPase as a modulator of apoptosis and autophagy. Molecules 22, 578. https://doi.org/10.3390/molecules220405 78 (2017).

47. Lemeshko, V. V. El papel de la membrana mitocondrial externa en el control del metabolismo energético celular. Rev. Acad. Colomb. Cienc. Ex. Fis. Nat. 42, 6-21. https://doi.org/10.18257/raccefyn.549 (2018).

48. Ichiba, T. \& Higa, T. New cuparene-derived sesquiterpenes with unprecedented oxygenation pattern from the sea hare Aplysia dactylomela. J. Org. Chem. 51, 3364-3366. https://doi.org/10.1021/jo00367a021 (1986).

49. Kladi, M., Xenaki, H., Vagias, C., Papazafiri, P. \& Roussis, V. New cytotoxic sesquiterpenes from the red algae Laurencia obtusa and Laurencia microcladia. Tetrahedron 62, 182-189. https://doi.org/10.1002/chin.200621178 (2006).

50. Groom, C. R., Bruno, I. J., Lightfoot, M. P. \& Ward, S. C. The cambridge structural database. Acta Cryst. B72, 171-179. https://doi. org/10.1107/S2052520616003954 (2016).

51. Sifaoui, I. et al. Ursolic acid derivatives as potential agents against Acanthamoeba spp. Pathogens. 8, 130. https://doi.org/10.3390/ pathogens8030130 (2019).

52. Sifaoui, I. et al. Toxic effects of selected proprietary dry eye drops on Acanthamoeba. Sci. Rep. 8, 8520. https://doi.org/10.1038/ s41598-018-26914-3 (2018).

\section{Acknowledgements}

This research was funded by PI18/01380 from Instituto de Salud Carlos III, Spain, CTQ2014-55888-C0301/R and PID2019-109476RB-C21 (MINECO), INTERREG-MAC/1.1b/042 (BIOTRANSFER2), and RICET [RD16/0027/0001 project, from Programa Redes Temáticas de Investigación Cooperativa, FIS (Ministerio Español de Salud, Madrid, Spain). IS and ARDM thank to Programa Agustín de Bethancourt, Cabildo de Tenerife, Spain. SGD thanks to CONACYT fellowship 740689. IAJ, ARL and RLRE were funded by Agencia Canaria de Investigación, Innovación y Sociedad de la Información and FEDER. Authors also acknowledge the use of General Research Support Services of University of La Laguna (SEGAI-ULL).

\section{Author contributions}

A.R.D.M., S.G.D., and J.J.F. processed the extract, conducted isolation of metabolites, chemical transformation and spectroscopic analysis of the chemical compounds. J.L.M., A.R.D.M., S.G.D., J.E.P.B. conducted selection of Laurencia compounds. I.A.J., A.R.L., J.L.M., R.L.R.E, M.R.B. and I.S. performed the evaluation of amoebicidal activity and their interpretation assays of Programmed Cell Death. Analysis and biological data compilation were performed by all authors. All authors contributed equally to the final version of the manuscript.

\section{Funding}

The funders had no role in the design of the study; in the collection, analyses, or interpretation of data; in the writing of the manuscript, or in the decision to publish the results.

\section{Competing interests}

The authors declare no competing interests.

\section{Additional information}

Supplementary information is available for this paper at https://doi.org/10.1038/s41598-020-74729-y.

Correspondence and requests for materials should be addressed to J.E.P., J.J.F. or J.L.-M.

Reprints and permissions information is available at www.nature.com/reprints.

Publisher's note Springer Nature remains neutral with regard to jurisdictional claims in published maps and institutional affiliations.

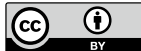

Open Access This article is licensed under a Creative Commons Attribution 4.0 International License, which permits use, sharing, adaptation, distribution and reproduction in any medium or format, as long as you give appropriate credit to the original author(s) and the source, provide a link to the Creative Commons licence, and indicate if changes were made. The images or other third party material in this article are included in the article's Creative Commons licence, unless indicated otherwise in a credit line to the material. If material is not included in the article's Creative Commons licence and your intended use is not permitted by statutory regulation or exceeds the permitted use, you will need to obtain permission directly from the copyright holder. To view a copy of this licence, visit http://creativecommons.org/licenses/by/4.0/.

(C) The Author(s) 2020 